\title{
The Effect of Various States of Hydration and the Plasma Concentration on the Turnover of Antidiuretic Hormone in Mammals *
}

\author{
J. W. Czaczkes † and C. R. Kleeman with the technical assistance of \\ RALPH Boston
}

(From the Departments of Medicine, Cedars-Sinai Hospitals, Mount Sinai Hospital Division, and the University of California Medical Center, Los Angeles, Calif.)

To evaluate the rate of production and turnover of antidiuretic hormone (ADH), it is essential to know its volume of distribution. Our previous paper (1), and those in the literature (2-4), have suggested that this volume approximates the plasma volume, and most authors have explained this as the result of binding of $\mathrm{ADH}$ to plasma proteins. In the accompanying study (1) on the physiology of ADH in man, we were unable to demonstrate the binding of the hormone to plasma proteins using in vitro ultrafiltration and dialysis techniques. Despite this, the volume of distribution of arginine-vasopressin, calculated from the injected dose and the extrapolated zero time concentration in the plasma, was only $2.5 \%$ of the body weight, a volume significantly less than plasma volume. We concluded, however, that under the circumstances of these experiments the volume calculated from the extrapolation technique was erroneously low. In the same study we found that the turnover rate of both endogenous and exogenous $\mathrm{ADH}$ (arginine-vasopressin) in humans was related to the state of hydration. Three days of dehydration significantly accelerated while a comparable period of sustained over hydration slowed the observed normal turnover rate.

The present study was undertaken in an effort to determine the true volume of distribution in animals, using a constant infusion technique, and to determine whether the fractional turnover rate

\footnotetext{
* Submitted for publication December 18, 1963; accepted April 27, 1964.

Supported by U. S. Public Health Service grant AM06427-01 and a grant from the Sandoz Co., Hanover, N. J.

$\dagger$ From the Laboratory of Clinical Research, Hadassah University Hospital and the Hebrew University-Hadassah Medical School, Jerusalem, Israel; Celia Davidson Fellow in metabolic and renal diseases.
}

was truly influenced by the state of hydration per se or by the different levels of circulating $\mathrm{ADH}$ resulting from the various states of hydration.

\section{Methods}

The fractional turnover rate and volume of distribution of endogenous and exogenous $A D H$

Dog experiments. 1) The disappearance curve of endogenous $A D H$ and injected arginine-vasopressin in the water-loaded animal. Four trained female dogs were deprived of fluids for 12 hours. At the start of the experiment a sample of blood was drawn from an indwelling needle in the foreleg vein, and the animals were hydrated by stomach tube with 800 to $1,000 \mathrm{ml}$ of tap water (5\% of body weight). This state of hydration was maintained by a continuous iv infusion of $2.5 \%$ glucose in $0.45 \%$ sodium chloride at a rate equivalent to urine output. At suitable intervals blood samples were obtained for ADH determination. Timed urine specimens were collected by an indwelling catheter. The osmolality of the urine samples was measured by freezing point depression, using a Fiske osmometer. ${ }^{1} \mathrm{ADH}$ was assayed by a modification of the bioassay of Heller and Stulc $(1,5)$. After maximal water diuresis was attained, two of the dogs were injected intravenously with $2.5 \mathrm{mU}$ of synthetic arginine-vasopression, 2 and its disappearance from the circulation was followed. From these data the fractional turnover rates and apparent volume of distribution were calculated.

2) Steady-state levels of ADH during a constant infusion of arginine-vasopressin into hydrated animals and after stopping the infusion. Two trained dogs were hydrated by stomach tube and prepared similar to the above experiments. At the point of maximal water diuresis, when the level of $\mathrm{ADH}$ was zero $(<0.25 \mu \mathrm{U}$ per $\mathrm{ml})$, vasopressin was added to the constant intravenous infusion.

One dog received $230 \mu \mathrm{U}$ per minute for 1 hour, then $470 \mu \mathrm{U}$ per minute for 1 additional hour and, finally, 1,700 $\mu \mathrm{U}$ per minute for 50 minutes. The second dog received

1 Fiske Associates, Inc., Bethel, Conn.

$2 \mathrm{Mr}$. Harry Althouse of the Sandoz Co., Hanover, N. J., donated the supplies of arginine-vasopressin. 
$4,000 \mu \mathrm{U}$ per minute under similar conditions. The volume of distribution of the infused vasopressin was calculated from the following relationship: $\mathrm{I} / \mathrm{V}=\mathrm{Kc}$ or $\mathrm{V}=\mathrm{I} / \mathrm{Kc}$, where $\mathrm{c}=$ the constant concentration of $\mathrm{ADH}$ in plasma attained during the infusion, $\mathrm{K}=$ fractional turnover rate per minute calculated from the slope of the semilog disappearance after the infusion of vasopressin is stopped, $\mathrm{I}=$ rate of infusion of $\mathrm{ADH}$ in microunits per minute, and $\mathrm{V}=$ volume of distribution. After the highest constant levels were attained in each animal (19 and $40 \mu \mathrm{U}$ per $\mathrm{ml}$, respectively), the vasopressin infusion was stopped, and the disappearance of the hormone from the circulation was followed.

An additional experiment was designed to examine the concentration of $\mathrm{ADH}$ in the interstitial space while the plasma level was elevated by a constant infusion of vasopression in a pentobarbital-anesthetized dog. Lymph was considered a reasonable approximation of interstitial fluid. The lymph samples were collected from a large vessel entering the cisterna chyli. To avoid contamination with liver lymph, the hepatic arteries were ligated. A portacaval shunt operation was performed to prevent venous stasis in the gastrointestinal tract subsequent to the arterial ligation. The ADH content of simultaneously collected samples of blood and lymph were compared.

Rat experiments. 1) The disappearance curve of $A D H$ after a single intraz'enous injection of arginine-vasopressin into hydrated rats. Female rats of the SpragueDawley strain weighing 100 to $130 \mathrm{~g}$ were divided into groups of three to five animals. The average weight in each group was $115 \mathrm{~g}$. The rats were hydrated and anesthetized by the intragastric administration in divided doses of $12 \%$ ethanol in water. A total volume of $8 \%$ of their body weight was administered. Immediately after the hydration, 25 animals (lot $\mathrm{A}$ ) were injected intravenously with $5 \mu \mathrm{U}$ and 43 animals (lot $\mathrm{B}$ ) with $150 \mu \mathrm{U}$ of arginine-vasopressin contained in $0.5 \mathrm{ml}$ of saline. All injections were given into a tail as rapidly as possible. One group ( 3 to 5 animals) in each lot was killed immediately after the injection by decapitation and their blood pooled for ADH assay. The bulk of the blood from each animal was collected in about $5 \mathrm{sec}-$ onds. This time was consistent from animal to animal. The other groups were killed similarly in intervals of 2 minutes. From the concentration of $\mathrm{ADH}$ in the plasma of the pooled blood of each group a disappearance curve was plotted.

2) "Steady-state" levels of ADH after constant infusion of arginine-vasopressin. Four rats weighing $120 \mathrm{~g}$ were hydrated as in the former experiment; 10 to 15 minutes after the hydration they were infused intravenously with $2.0 \mu \mathrm{U}$ per minute of arginine-vasopressin for 1 hour. The infusion was continued up to the moment of decapitation, and their blood was collected individually into heparinized tubes. From the ADH concentration of their plasma the volume of distribution was calculated using the formula described above in the dog experiments. The $K$ value used for these 4 rats was that derived from the experiments in the above paragraph (1).

3) Turnover rate of circulating endogenous $A D H$ in a patient with wasopressin-resistant and three patients with vasopressin-sensitive diabetes insipidus. Patient D.K., a 53-year-old male with congenital nephrogenic diabetes insipidus, was described in detail in a previous publication (6). Thiazide diuretics were discontinued 2 weeks before the experiment. On the day before the experiment a random sample of blood was drawn and assayed for its $\mathrm{ADH}$ activity. On the day of the experiment the patient was taken off fluids for slightly longer than 2 hours. At the end of this period he complained of severe headache, muscle weakness, and extreme thirst. He described these symptoms as typical of water deprivation of this duration. After procaine infiltration an indwelling needle was painlessly inserted into a forearm vein, and a blood sample was taken for zero time concentration of $\mathrm{ADH}$ in his plasma. Immediately after this a rapid infusion ( $20 \mathrm{ml}$ per minute) of $0.45 \%$ sodium chloride was started and continued for 52 minutes. $\mathrm{He}$ then drank $1,000 \mathrm{ml}$ of water and continued drinking in amounts equal to his urine output. After 50 minutes the patient was taken off fluids and the experiment continued for another hour. During the whole test he reclined in bed, standing only to void. At suitable intervals samples of blood were drawn for ADH assay, timed urine samples were collected, and their osmolality was determined. Similar experiments were carried out on three patients with vasopressin-sensitive diabetes insipidus. The only difference was that these patients were hydrated orally. They initially drank 1,000 to $1,500 \mathrm{ml}$ of water and subsequently orally replaced a volume equivalent to urinary output. Patient S.P., a 30-year-old female, had congenital diabetes insipidus and anterior pituitary insufficiency secondary to removal of a craniopharyngioma at the age of 9. He had been maintained on glucocorticoid, thyroid, and androgen replacement therapy that was not interrupted for the present experiments. Both of these patients stopped their Pitressin tannate therapy 72 hours before the experiments. The third patient, S.K., a 29 year-old male, developed diabetes insipidus of undetermined etiology in early childhood. The diagnosis was confirmed, and the present experiment was carried out during the same hospital admission. Before this admission he had never received therapy for his disease. $\mathrm{Pa}$ tients S.P., B.G., and S.K. were injected with 10, 10, and $25 \mathrm{mU}$ of arginine-vasopressin, respectively.

Ultrafiltration and dialysis of endogenous $A D H$. Forty $\mathrm{ml}$ of blood was drawn from each of four dogs after 15 hours of water deprivation, and $40 \mathrm{ml}$ was pooled from ten decapitated rats after a similar period of water restriction. Immediately after clotting, the serum was separated and part of it placed in Lavietes (7) anaerobic ultrafiltration units at both $20^{\circ}$ and $37^{\circ} \mathrm{C}$. One unit, set up in such a way that no ultrafiltration occurred, served as a control. Two $10-\mathrm{ml}$ samples of dog and one $10-\mathrm{ml}$ pooled sample of rat serum were each dialyzed against $50 \mathrm{ml}$ 
TABLE I

The disappearance of endogenous and exogenous vasopressin in water-loaded dogs*

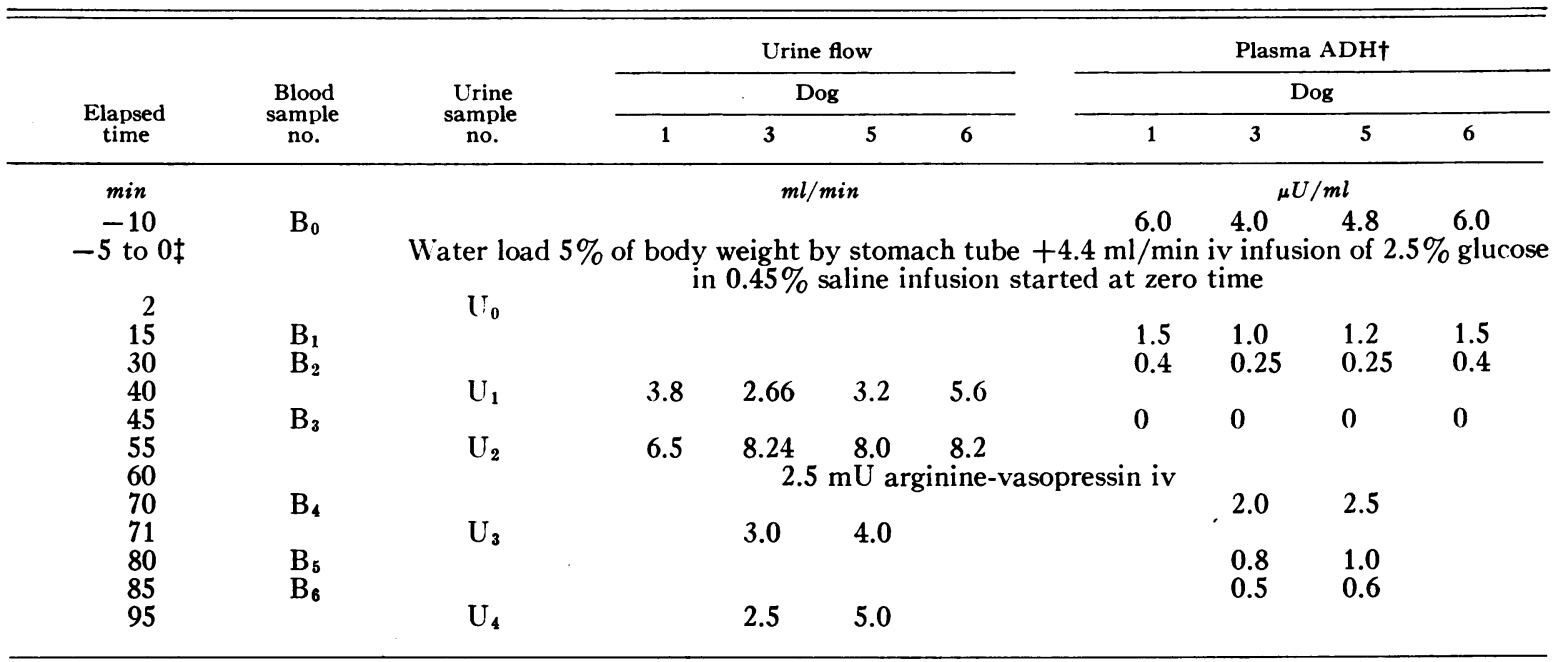

* Dog weights $(\mathrm{kg}): 1=15.5,3=18.4,5=15.0$, and $6=20.9$.

$+\mathrm{ADH}=$ antidiuretic hormone.

$\ddagger$ Completion of the oral water load represents zero time. The zero-time plasma concentration of ADH is considered equal to the basal steady-state plasma level. This assumes that the ADH concentration in the plasma has not changed appreciably during the 5 minutes of gavage.

Ringer's solution for 6 hours at $37^{\circ} \mathrm{C}$ with continuous stirring, by the technique described by Craig and King (8). The dialysis bag was filled completely so that no visible air space was left. In both ultrafiltration and dialysis Visking membrane ${ }^{3}$ was used. The ADH content of the ultrafiltrates, the control serums, and the fluid on both sides of the dialyzing membrane were determined.

\section{Results}

The fractional turnover rate and volume of distribution of endogenous and exogenous $A D H$

Dog experiments. Table I shows the results of four dog experiments, and Figure 1 demonstrates the disappearance curves of endogenous and exogenous ADH. The basal concentrations of $\mathrm{ADH}$ in microunits per milliliter in the plasma of these animals were $6.0,4.0,4.8$, and 6.0 , respectively. The disappearance curve of endogenous and exogenous $\mathrm{ADH}$ approximated a straight line when plotted on semilogarithmic paper. The slope of these lines is extremely constant, representing a fractional turnover of 0.0924 per minute and a $t_{1}$ of $7 \frac{1}{2}$ minutes. Figure 2 compared the above curves with those of two hydrated dogs whose

3 Dialyzing tubing by Division of American Hospital Supply Corp., Evanston, Ill. plasma level of $\mathrm{ADH}$ was raised to 19 and $40 \mu \mathrm{U}$ per $\mathrm{ml}$, respectively, by continuous intravenous infusion of arginine-vasopressin. The slopes from the higher values down to $10 \mu \mathrm{U}$ per $\mathrm{ml}$ are steeper, whereas below $10 \mu \mathrm{U}$ per $\mathrm{ml}$ they are similar (Figure 2). The fractional turnover rate for the steeper part of the curve is 0.139 per minute, and the $t_{1}$ is $\mathbf{5}$ minutes.

Rat experiments. Table II gives the results in

TABLE II

Disappearance curve of exogenous $A D H$ from hydrated rats after iv injection of 5 and $150 \mu U$ arginine-vasopressin

\begin{tabular}{|c|c|c|c|c|}
\hline \multirow[b]{2}{*}{$\begin{array}{c}\text { Elapsed } \\
\text { time }\end{array}$} & \multicolumn{2}{|r|}{ Lot A } & \multicolumn{2}{|r|}{ Lot $B$} \\
\hline & $\begin{array}{l}\text { Normal } \\
\text { rats in } \\
\text { group }\end{array}$ & $\begin{array}{l}\text { Plasma ADH } \\
\text { content of } \\
\text { pooled blood }\end{array}$ & $\begin{array}{l}\text { No. of } \\
\text { rats in } \\
\text { group }\end{array}$ & $\begin{array}{l}\text { Plasma ADH } \\
\text { content of } \\
\text { pooled blood }\end{array}$ \\
\hline $\min$ & \multirow{3}{*}{\multicolumn{2}{|c|}{$\begin{array}{cc} & \mu U / m l \\
3 & 0 \\
5 \mu \mathrm{U} \text { arginine- } \\
\text { vasopressin iv }\end{array}$}} & \multirow{3}{*}{\multicolumn{2}{|c|}{$\begin{array}{l}3 \\
150 \mu \mathrm{U} \text { arginine- } \\
\text { vasopressin iv }\end{array}$}} \\
\hline-1 & & & & \\
\hline 0 & & & & \\
\hline 0.1 & 5 & 1.6 & 5 & 50 \\
\hline 2 & 5 & 1.1 & 4 & 20 \\
\hline 4 & 4 & 0.7 & 5 & 8 \\
\hline 6 & 4 & $>0.25<0.5$ & 3 & 4 \\
\hline 8 & 4 & 0 & 5 & 2 \\
\hline 10 & & & 4 & 1.3 \\
\hline 12 & & & 4 & 0.9 \\
\hline 14 & & & 4 & 0.6 \\
\hline 16 & & & 3 & $>0.25<0.5$ \\
\hline 18 & & & 3 & 0 \\
\hline
\end{tabular}




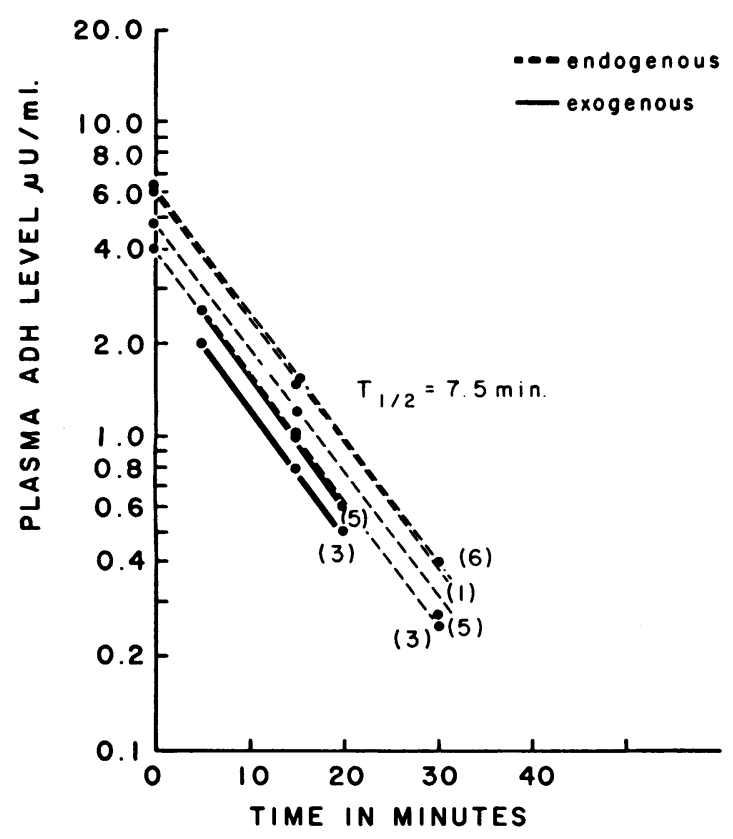

Fig. 1. Disappearance of endogenous and exogeNOUS ANTIDIURETIC HORMONE (ADH) (ARGININE-VASOPRESSIN) FROM the Plasma OF HydRATEd Dogs. The lines represent visual approximation to the points. In the curves representing the disappearance of endogenous $\mathrm{ADH}$, the basal steady-state concentration obtained 5 minutes before the gavage (see Table I) is considered the zero-time plasma concentration. To avoid further overlap of the points, the curves for exogenous $\mathrm{ADH}$ have been drawn through points at 5,15 , and 20 minutes rather than (see Table I) 10, 20, and 25 minutes, the times the samples were collected.

the two rat experiments. After hydration the rat plasma contained no ADH activity, and immediately after the injection of vasopressin, plasma levels of 1.6 and $50 \mu \mathrm{U}$ per $\mathrm{ml}$ were obtained. The pooled values fell in an exponential way (Figure 3 ). In the first experiment (curve 1), starting with a plasma level of $1.6 \mu \mathrm{U}$ per $\mathrm{ml}$, one straight semilogarithmic line was obtained. The fractional turnover rate was 0.203 per minute, the $t_{1}, 3.4$ minutes. In the second experiment (curve 2 ), starting with a plasma level of $50 \mu \mathrm{U}$ per $\mathrm{ml}$, three different slopes were obtained, the steepest being associated with the highest $\mathrm{ADH}$ levels. The disappearance curve from 50 to $8 \mu \mathrm{U}$ per $\mathrm{ml}$ corresponds to a fractional turnover of 0.462 per minute and $a t_{\frac{1}{2}}$ of 1.5 minutes; from 8 to $2 \mu \mathrm{U}$ per $\mathrm{ml}$, to a fractional turnover of 0.362 and a $t_{1}$ of 2 minutes; below $2 \mu \mathrm{U}$ per $\mathrm{ml}$ the fractional turnover and $t_{\frac{1}{2}}$ were identical with the former experiment (curve 1) (0.203 per minute and 3.4 minutes). These results, demonstrating the relationship of fractional turnover to plasma concentration of $\mathrm{ADH}$, are similar to those of the dog experiments (Figure 2).

\section{Volume of distribution}

After intravenous injection of vasopressin into hydrated animals (rats and dogs) the apparent volume of distribution was calculated with the injected amount of $\mathrm{ADH}$ and the zero time concentration arrived at by extrapolating the disappearance curve to the ordinate. The results were tabulated in Table III, and the apparent volume of distribution was expressed as a percentage of the body weight. This value averages $2.6 \%$ of the body weight.

Table IV gives the relevant data for the calcu-

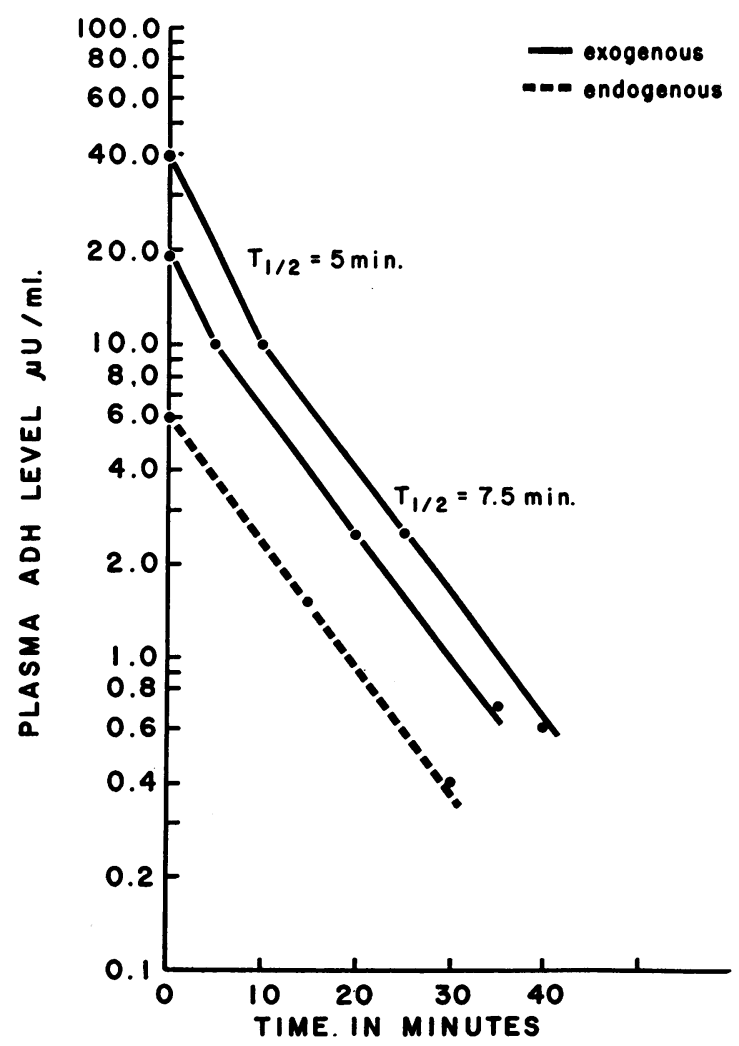

Fig. 2. Disappearance of ARgININE-VASOPRESSIN FROM THE PLASMA OF TWO HYDRATED DOGS AFTER THE CONCENTRATIONS HAD BEEN ELEVATED BY CONTINUOUS INTRAVENous infusion. The curve to the left is derived from the values in Figure 1. The lines represent visual approximation to the points. 


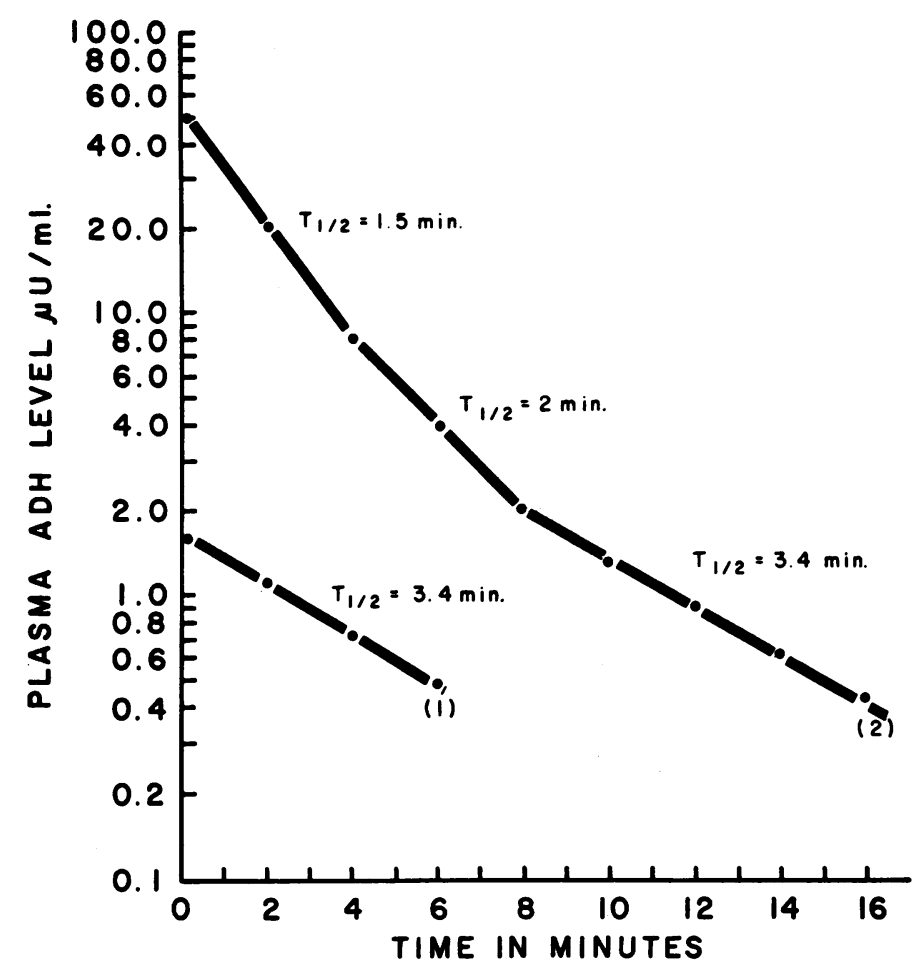

Fig. 3. Disappearance of ARginine-VASOPRESSIN FROM THE PLASMA OF HYDRATED RATS AFTER INTRAVENOUS INJECTION. The lines represent a visual approximation to the points. The lowest points on both curves represent concentrations between 0.25 and $0.5 \mu \mathrm{U}$ per ml (see Table II).

lation of the volume of distribution derived from steady-state levels of plasma $\mathrm{ADH}$ after continuous infusion of known amounts of arginine-vasopressin into dogs and rats (see Methods). The volume of distribution is expressed again as a percentage of body weight, and this value is averaged (4\% in the dogs and $4.2 \%$ in the rats). Table $\mathrm{V}$ gives the ADH content of simultaneously collected lymph and plasma in the surgically prepared dog (see Methods). With plasma levels of $\mathrm{ADH}$ maintained over $200 \mu \mathrm{U}$ per $\mathrm{ml}$, the con- centration of $\mathrm{ADH}$ in the lymph remained below $1.0 \mu \mathrm{U}$ per $\mathrm{ml}$, thus supporting the assumption that the plasma compartment represents the true volume of distribution.

Vasopressin-resistant diabetes insipidus (patient D.K.). In Table VI are the tabulated results of the experiment. A random sample of blood drawn on the day before the experiment while the patient was allowed free access to water contained $4.3 \mu \mathrm{U}$ per $\mathrm{ml}$. On the day of the experiment, despite a weight loss of $1 \mathrm{~kg}$ after 2 hours of wa-

TABLE III

Apparent volume of distribution of injected $A D H$ (arginine-vasopressin) in dogs and rats

\begin{tabular}{|c|c|c|c|c|c|}
\hline Animal & $\begin{array}{l}\text { Extrapolated } \\
\text { zero value }\end{array}$ & $\begin{array}{l}\text { Injected amount } \\
\text { of ADH }\end{array}$ & Wt of animal & Vol of distribution & $\begin{array}{l}\text { Vol of distribution } \\
\text { as \% of body wt }\end{array}$ \\
\hline \multirow[b]{5}{*}{ Lot B } & $\mu U / m l$ & $m U$ & $k g$ & $m l$ & $\%$ \\
\hline & 5.0 & 2.5 & 18.4 & 500 & 2.7 \\
\hline & 6.0 & 2.5 & 15.0 & 420 & 2.8 \\
\hline & 17 & & 0115 & 293 & 25 \\
\hline & $52^{1.1}$ & 0.150 & 0.115 & $\begin{array}{l}2.9 .9 \\
2.99\end{array}$ & $\begin{array}{l}2.5 \\
2.5\end{array}$ \\
\hline
\end{tabular}


TABLE IV

Volume of distribution of ADH (arginine-vasopressin) calculated from steady states attained after constant infusion of the hormone into dogs and rats

\begin{tabular}{|c|c|c|c|c|c|c|}
\hline Animal & $\begin{array}{c}\text { Infused amount } \\
\text { of } A D H \\
\text { (I) }\end{array}$ & $\begin{array}{l}\text { Steady-state } \\
\text { concentration } \\
\text { of ADH } \\
\text { (c) }\end{array}$ & $\mathrm{K}^{*}$ & $\begin{array}{l}\text { Volume of } \\
\text { distribution } \\
\text { (V) }\end{array}$ & Body wt & $\begin{array}{c}\text { Volume as } \% \\
\text { of body wt }\end{array}$ \\
\hline & $\mu U / \min$ & $\mu U / m l$ & & $m l$ & $\mathrm{~kg}$ & \\
\hline Dog 1 & 4.000 & 40.00 & 0.139 & 721 & 19.0 & 3.8 \\
\hline \multirow{3}{*}{ Dog 2} & 230 & 4.05 & $0.0924 \dagger$ & 617 & 15.5 & 4.0 \\
\hline & 470 & 8.15 & $0.0924 \dagger$ & 625 & 15.5 & 4.05 \\
\hline & 1,700 & 19.00 & 0.139 & 645 & 15.5 & 4.15 \\
\hline Rat 1 & 2.0 & 1.8 & $0.203 \ddagger$ & 5.47 & 0.120 & 4.56 \\
\hline Rat 2 & 2.0 & 2.0 & $0.203 \ddagger$ & 4.92 & 0.120 & 4.10 \\
\hline Rat 3 & 2.0 & 2.1 & $0.203 t$ & 4.80 & 0.120 & 4.00 \\
\hline Rat 4 & 2.0 & 1.9 & $0.203 \ddagger$ & 5.2 & 0.120 & 4.35 \\
\hline
\end{tabular}

* Fractional turnover rate per minute; see figures. $\mathrm{V}=\mathrm{I} / \mathrm{Kc}$.

$\dagger$ These values for $K$ were obtained from the semilog disappearance curve in this dog after a single intravenous injection of arginine-vasopressin. See Figure 1.

$\ddagger$ The value of $\mathrm{K}$ for the rats was derived from the lot $\mathrm{A}$ experiments shown in Table II and Figure 3 .

ter deprivation, the concentration of $\mathrm{ADH}$ in the initial sample $\left(B_{0}\right.$ in Table VI) was no higher than in the random sample. Under the influence of rehydration the ADH levels fell in an exponential manner (Figure 4, curve 1). Despite the fact that this patient was hydrated by a rapid continuous intravenous infusion, while the previously described (1) normal subjects were hydrated orally, the slopes of the first part of their curves were very similar. The fractional turnover rate calculated from the second part of curve 1, Figure 4, was 0.0693 per minute, and the $t_{3}$ was 10 minutes. This value was very similar to that observed in normal subjects after 3 days of dehydration (1). As shown in Table VI, after all water ingestion stopped the plasma level returned to $3.0 \mu \mathrm{U}$ per $\mathrm{ml}$ in 1 hour. In contrast,

TABLE $\mathrm{V}$

Protocol of simultaneous blood and lymph collection in a dog after portacaval shunt operation and ligation of the hepatic artery

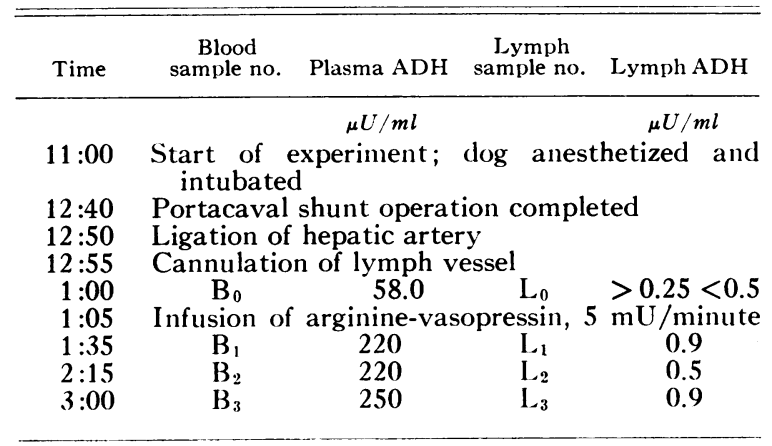

a previously tested normal subject required, in a similar experiment, 90 minutes to reach a plasma level of less than $2.0 \mu \mathrm{U}$ per $\mathrm{ml}$ (1). The rapid return in this patient occurred despite the fact that his fractional turnover rate of ADH was significantly greater than normal.

Vasopressin-sensitive diabetes insipidus (patients S.P., B.G., and S.K.). Figure 4 (curves 2,3 , and 4) demonstrates the disappearance of the injected arginine-vasopressin from the circulation of these three patients. The slopes are very similar to the second part of the curve in the patient with Pitressin-resistant diabetes insipidus. The fractional turnover rates and $t_{3}$ for patients S.P., B.G., and S.K. were $0.057,0.057$, and 0.053 ; 12,12 , and 13 minutes, respectively.

Ultrafiltration and dialysis. Examination of Table VII indicates that in the in vitro systems utilized, plasma $\mathrm{ADH}$ was completely ultrafilterable as well as dialyzable.

\section{Discussion}

In a previous study (1) on the metabolism of $\mathrm{ADH}$, the state of hydration significantly altered the turnover rate of the hormone. Three days of dehydration increased and three days of overhydration decreased the turnover rate. The above states of hydration were associated with a high and zero $(<0.25 \mu \mathrm{U}$ per $\mathrm{ml})$ concentration of $\Lambda \mathrm{DH}$, respectively, and it was not possible in these earlier experiments to determine whether the 
varying turnover rates were primarily due to the altered $\mathrm{ADH}$ level or to the state of hydration per se. In the dog and rat experiments of the present study it was possible to observe the effect of various levels of $\mathrm{ADH}$ on the turnover rate while a constant state of hydration was maintained. In dogs a $t_{1}$ of $7 \frac{1}{2}$ minutes was observed when the plasma level of $\mathrm{ADH}$ was below $10 \mu \mathrm{U}$ per $\mathrm{ml}$, while between 40 and $10 \mu \mathrm{U}$ per $\mathrm{ml}$ the $t_{\frac{1}{3}}$ was shortened to 5 minutes. This shorter $t_{1}$ was similar to that calculated by Lauson and Bocanegra (9) in experiments on pentobarbital-anesthetized dogs receiving constant infusions of bovine Pitressin. When they elevated the plasma level of $\mathrm{ADH}$ to between 80 and $2,000 \mu \mathrm{U}$ per $\mathrm{ml}$ they found that after stopping the infusion the concentration fell within 15 minutes to about $14 \%$ of the steadystate level. Assuming a semilogarithmic disappearance, they calculated a mean $t_{1}$ of 5.4 minutes and a fractional turnover rate of $12.9 \%$ per minute. In the rats a $t_{1}$ of 3.4 minutes was observed at a concentration below $2 \mu \mathrm{U}$ per $\mathrm{ml}$; between 8 and $2 \mu \mathrm{U}$ per $\mathrm{ml}$ the $\mathrm{t}_{\frac{1}{2}}$ was 2.0 minutes, whereas be-

TABLE VI

The effect of water restriction followed by intravenous and oral hydration on circulating $A D H$ and water diuresis in patient $D$. $K$. (vasopressin-resistant diabetes insipidus)

\begin{tabular}{|c|c|c|c|c|c|}
\hline$\underset{\text { time }}{\text { Elapsed }}$ & $\begin{array}{c}\text { Blood } \\
\text { sample } \\
\text { no. }\end{array}$ & $\begin{array}{c}\text { Urine } \\
\text { sample } \\
\text { no. }\end{array}$ & $\begin{array}{l}\text { Urine } \\
\text { flow }\end{array}$ & $\begin{array}{c}\text { Urine } \\
\text { osmolality }\end{array}$ & $\underset{\text { ADH }}{\text { Plasma }}$ \\
\hline $\min$ & \multirow{2}{*}{\multicolumn{5}{|c|}{$\begin{array}{cc}m l / m i n & m O s m / L \\
\text { Ingestion of water stopped }\end{array}$}} \\
\hline-130 & & & & & \\
\hline-78 & & $\mathrm{U}_{0}$ & & 103 & \\
\hline-35 & & $\mathrm{U}_{1}$ & 8.6 & 105 & \\
\hline-5 & \multirow{2}{*}{\multicolumn{5}{|c|}{$\begin{array}{c}\mathrm{B}_{0} \\
\text { Infusion of } 0.45 \% \text { sodium chloride at } 20 \mathrm{ml} / \mathrm{min}\end{array}$}} \\
\hline 0 & & & & & \\
\hline 4 & & $\mathrm{U}_{2}$ & 9.2 & 105 & \\
\hline 10 & $\mathrm{~B}_{1}$ & $U_{0}$ & 0 & 02 & 3.4 \\
\hline 20 & $\mathrm{~B}_{2}$ & $U_{3}$ & 9.4 & 93 & 2.9 \\
\hline 30 & $\mathbf{B}_{3}$ & & & & 2.0 \\
\hline 35 & & $\mathrm{U}_{4}$ & 10.0 & 93 & \\
\hline $\begin{array}{l}40 \\
50\end{array}$ & $\begin{array}{l}\mathrm{B}_{4} \\
\mathrm{~B}_{5}\end{array}$ & & & & $\begin{array}{l}4.0 \\
0.5\end{array}$ \\
\hline 52 & \multicolumn{5}{|c|}{$\begin{array}{l}\text { Infusion stopped and oral water } \\
\text { replacement begun }\end{array}$} \\
\hline $\begin{array}{l}57 \\
72\end{array}$ & & $\begin{array}{l}\mathrm{U}_{5} \\
\mathrm{U}_{6}\end{array}$ & $\begin{array}{l}10.0 \\
10.5\end{array}$ & $\begin{array}{l}93 \\
86\end{array}$ & \\
\hline 80 & $\mathrm{~B}_{6}$ & 8 & & & 0 \\
\hline 110 & $\mathrm{~B}_{7}$ & $U_{7}$ & 10.0 & 90 & 0 \\
\hline $\begin{array}{l}116 \\
136\end{array}$ & & $\begin{array}{c}\text { Ingesti } \\
\mathrm{U}_{8} \\
\mathrm{U}_{9}\end{array}$ & $\begin{array}{c}\text { of wat } \\
9.0 \\
9.3\end{array}$ & $\begin{array}{c}\text { stopped } \\
86 \\
87\end{array}$ & \\
\hline $\begin{array}{l}140 \\
156\end{array}$ & $\mathrm{~B}_{8}$ & $\mathrm{U}_{10}$ & 10.0 & 88 & 1.6 \\
\hline 170 & $\mathrm{~B}_{9}$ & & & & 3.0 \\
\hline
\end{tabular}

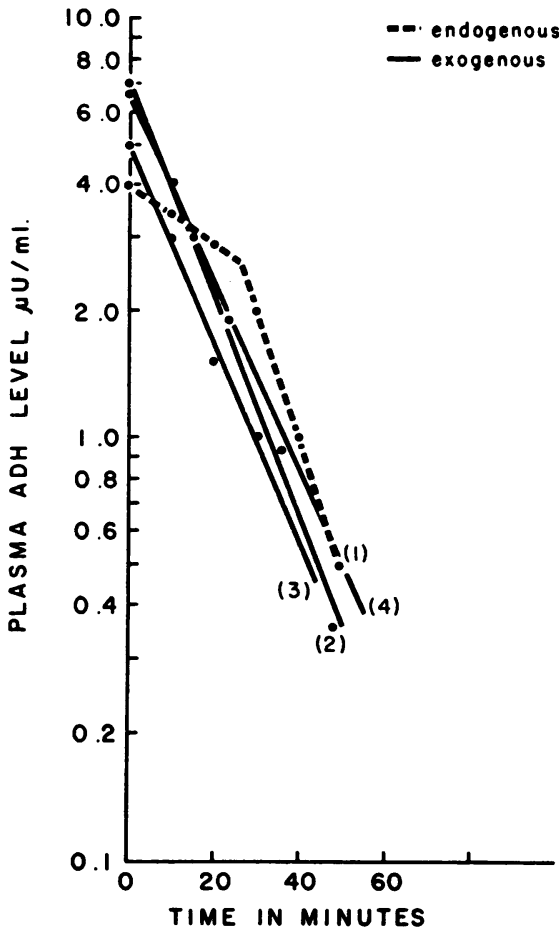

Fig. 4. Disappearance of endogenous ADH From THE PLASMA OF A PATIENT WITH VASOPRESSSIN-RESISTANT DIABETES INSIPIDUS (1) AFTER AN INTRAVENOUS AND ORAL WATER LOAD AND THE DISAPPEARANCE OF ARGININE-VASOPRESSIN FROM THE PLASMA OF THREE PATIENTS WITH VASOPRESSIN-SENSITIVE DIABETES INSIPIDUS (2, 3, AND 4) AFTER INTRAVENOUS INJECTION. The zero-time value represents the concentration in the plasma 10 minutes after the injection. The lines represent visual approximation to the points.

tween 50 and $8 \mu \mathrm{U}$ per $\mathrm{ml}$ the $\mathrm{t}_{\frac{1}{2}}$ was 1.5 minutes. Ginsburg (10) and Ginsburg and Heller (11), utilizing the antidiuretic activity of blood after the intravenous injection of Pitressin, ${ }^{4}$ estimated its half-life in the circulation to be about $1 \mathrm{~min}$ ute with a plasma clearance and fractional turnover of $100 \%$ per minute. Recently Sawyer, Chan, and Van Dyke (12) demonstrated that the mean half-life of the vasopressor response to the injection of $4 \mathrm{mU}$ of arginine-vasopressin was 2.05 minutes. Ginsburg's results $(10,11)$ compare favorably with the $t_{1}$ observed in the present study for $\mathrm{ADH}$ levels between 50 and $8 \mu \mathrm{U}$ per $\mathrm{ml}$. Although there may be some question about the validity of comparing the duration of a pressor response to the level of antidiuretic activity as

\footnotetext{
4 Parke, Davis \& Co., Detroit, Mich.
} 
TABLE VII

Concentration of endogenous $A D H$ in anaerobic ultrafiltrate and in dialyzate compared with control plasma

\begin{tabular}{clccc}
\hline \hline \multirow{2}{*}{ Material } & Procedure & Temp. & $\begin{array}{c}\text { ADH in } \\
\text { filtrate or } \\
\text { dialyzate }\end{array}$ & $\begin{array}{c}\text { ADH in } \\
\text { control }\end{array}$ \\
\hline \multirow{3}{*}{ Dog serum } & Ultrafiltration & 20 & 5.9 & 6.0 \\
& Ultrafiltration & 20 & 6.0 & 5.8 \\
& Ultrafiltration & 37 & 4.2 & 4.3 \\
\multirow{2}{*}{ Rat serum } & Ultrafiltration & 37 & 4.8 & 4.7 \\
\multirow{2}{*}{ Dog serum } & Ultrafiltration & 20 & 8.4 & 8.0 \\
& Ultrafiltration & 37 & 6.8 & 6.6 \\
Rat serum & Dialysis & 37 & 3.2 & 3.0 \\
& Dialysis & 37 & 3.1 & 3.1 \\
& Dialysis & 37 & 5.4 & 5.2 \\
\hline & & & & \\
\hline
\end{tabular}

measured in our study, the half-life of $2.05 \mathrm{~min}$ utes is very similar to the 2.0 minutes observed between 8 and $2 \mu \mathrm{U}$ per $\mathrm{ml}$. However, when the concentration of $\mathrm{ADH}$ in plasma approaches the more physiologic range $(<2$ to $3 \mu \mathrm{U}$ per $\mathrm{ml}$ ), the $t_{\frac{1}{2}}$ was significantly longer. The results of the present study seem to indicate that the level of circulating $\mathrm{ADH}$ per se does influence the turnover rate.

On the other hand, all four patients with diabetes insipidus demonstrated turnover rates that were significantly greater than normal. This was despite the fact that the tissues of untreated patient S.K. were not exposed to ADH; those of patient D.K. (vasopressin-resistant diabetes insipidus) were exposed continuously to higher concentrations $(4 \mu \mathrm{U}$ per $\mathrm{ml}$ ) than observed in normally hydrated subjects $(2 \mu \mathrm{U}$ per $\mathrm{ml}$ ) (1), and those of the other two patients (S.P. and B.G.) intermittently exposed to high and low concentrations of $\mathrm{ADH}$ as a result of treatment. The only evident common denominator in these four patients was the presence of varying periods of mild to moderate dehydration extending over many years.

If the assumption is correct that the factors controlling the turnover of $\mathrm{ADH}$ are similar in all mammals, we may conclude that both the concentration of $\mathrm{ADH}$ in plasma and the state of hydration influence the peripheral disposal of ADH. Under physiological conditions of enhanced secretion, both factors would tend to lower plasma levels of the hormone and therefore protect the organism from any adverse cardiovascular effects of vasopressin.
The enhanced disposal of $\mathrm{ADH}$ at higher plasma levels might reasonably be explained by the effect of increased amounts of substrate on the enzyme (s) systems involved in inactivation of the hormone (13). However, the mechanisms by which the state of hydration could influence hormonal turnover remain unclear.

Volume of distribution. In a previous study in man the apparent volume of distribution determined by the extrapolation technique after injection of arginine-vasopressin into hydrated subjects was found to be $2.6 \%$ of the body weight (1). It was assumed that the true volume of distribution was probably equivalent to plasma volume and that the calculated volume, for unknown reasons, was erroneously low. In the present study volume of distribution in dogs and rats was also $2.6 \%$ of the body weight when calculated by extrapolation (Table III). We are again at a complete loss to explain this low volume of distribution particularly when at least in the $\mathrm{dog}$, at low plasma concentrations, the $\mathrm{K}$, or fraction of the volume of distribution cleared per minute, is the same for endogenous and exogenous $\mathrm{ADH}$ (Figure 1).

Lauson and Bocanegra (9) in the dog experiments described above calculated the apparent volume of distribution of $\mathrm{ADH}$ from the semilog disappearance curve after stopping the constant infusion. The apparent volume ranged from 0.98 to 1.34 times the true plasma volume ( $\mathrm{T}-1824)$. To overcome the error introduced in our studies by the extrapolation technique, arginine-vasopressin was constantly infused until a prolonged constant plasma level was achieved. Under these conditions we can reasonably assume that equilibration in the true volume of distribution occurred. From the rate of infusion, the fractional turnover rate, and the steady-state concentration of vasopressin in plasma, it was possible to calculate this volume (Table IV). The mean value of $4 \%$ of body weight reasonably approximates the known plasma volume in these species (14). The detection of less than $1 \mu \mathrm{U}$ per $\mathrm{ml}$ of $\mathrm{ADH}$ in the lymph while plasma levels were maintained above $200 \mu \mathrm{U}$ per $\mathrm{ml}$ (Table V) affords additional evidence that $\mathrm{ADH}$ is distributed in a space equivalent to plasma volume. 
TABLE VIII

Neurohypophyseal secretion rate of $A D H$ necessary to maintain steady-state plasma levels of $4.0 \mu U$ per $\mathrm{ml}$ in human, dog, and rat

\begin{tabular}{|c|c|c|c|c|c|}
\hline Species & $\begin{array}{c}\text { Estimated } \\
\text { plasma } \\
\text { vol }\end{array}$ & $\mathbf{K}^{*}$ & $\begin{array}{l}\text { Steady- } \\
\text { state } \\
\text { secretion }\end{array}$ & $\begin{array}{l}\text { Surface } \\
\text { areat }\end{array}$ & $\begin{array}{l}\text { Steady- } \\
\text { state } \\
\text { secretion }\end{array}$ \\
\hline & $m l$ & & $\mu U / \min$ & $m^{2}$ & $\mu U / m_{m^{2}}^{\min } /$ \\
\hline $\begin{array}{c}\text { Man } \\
\text { (normal) } \\
70 \mathrm{~kg}\end{array}$ & 3,200 & 0.0433 & 555 & 1.73 & 320 \\
\hline $\begin{array}{c}\text { Dog } \\
\text { (normal) } \\
20 \mathrm{~kg}\end{array}$ & 900 & 0.0924 & 330 & 0.86 & 383 \\
\hline $\begin{array}{c}\text { Rat } \\
\text { (normal) } \\
100 \mathrm{~g}\end{array}$ & 4 & 0.362 & 5.8 & 0.016 & 362 \\
\hline
\end{tabular}

* Fractional turnover rate per minute.

+ Surface area of dog and rat was calculated according to the formula S.A. $\left(\mathrm{cm}^{2}\right)=\mathrm{W}^{3} \cdot \mathrm{K}$, where $\mathrm{W}=$ weight in grams. K values were taken from Table 146 of the Handbook of Biological Data, National Academy of Science, National Research Council. Philadelphia, W. B. Saunders Co., 1961.

As previously reported for human plasma (1), the authors were unable to detect binding of $\mathrm{ADH}$ to plasma proteins of the dog and rat in vitro (Table VII). The results in the dog resemble those of Bocanegra and Lauson (15). However, our failure to demonstrate protein binding of the hormone in the rat conflicts with the observations of Thorn and Silver (4). These authors were measuring the protein binding of very high concentrations of endogenous ADH released under the powerful stimulus of severe hemorrhage in contrast to the relatively low concentrations studied in the present investigation (Table VII). We must assume from our results that either the hormone is bound in vivo, but not in vitro, to the plasma proteins, or that the capillary membrane is a significant barrier to the free diffusion of arginine-vasopressin.

Knowing the volume of distribution and the fractional turnover rates of the hormone in man, dog, and rat, it was possible to calculate the approximate rate of secretion from the neural lobe for any given steady-state concentration of $\mathrm{ADH}$ in the plasma. In Table VIII the calculated secretion rates for a plasma level of $4 \mu \mathrm{U}$ per ml are tabulated for these three species. Per square meter of surface area the secretion rates were very similar ( 300 to $380 \mu \mathrm{U}$ per $\mathrm{m}^{2}$ per minute).
The conclusions of Lauson and Bocanegra (9) and Ginsburg and Smith (16) that there is a definite relationship between body size and the fractional turnover rate and half-life of ADH are confirmed. The smaller the animal and the smaller the plasma volume, the greater the $\mathrm{K}$. This results in the relationship shown in Table VIII.

\section{Summary}

1) The turnover rates of endogenous and exogenous antidiuretic hormone (ADH) (argininevasopressin) were determined in dogs, rats, and patients with vasopressin-sensitive and vasopressin-resistant diabetes insipidus by utilizing a sensitive bioassay technique.

2) In the rat and dog we found that at higher plasma levels the turnover of the hormone was more rapid.

3) In all four patients the hormonal turnover was significantly faster than observed in normal subjects during comparable states of hydration.

4) We concluded that both the plasma level of $\mathrm{ADH}$ and the state of hydration influenced the peripheral disposal of the hormone.

5) The volume of distribution of $\mathrm{ADH}$, determined by a constant infusion technique, and the rate of disappearance of the hormone after stopping the infusion, approximated the assumed plasma volume. This was substantiated by finding less than $1 \mu \mathrm{U}$ per $\mathrm{ml}$ in lymph at a time when the plasma level was above $200 \mu \mathrm{U}$ per ml.

\section{References}

1. Czaczkes, J. W., C. R. Kleeman, and M. Koenig. Physiologic studies of antidiuretic hormone by its direct measurement in human plasma. J. clin. Invest. $1964,43,1625$.

2. Lauson, H. D. Vasopressin and oxytocin in the plasma of man and other mammals in Hormones in Human Plasma, 1st ed. Harry N. Antoniades, Ed. London, J. \& A. Churchill, 1960, p. 274.

3. Heller, $\mathrm{H}$. The state and concentration of the neurohypophysial hormones in the blood. Unpublished data cited by $\mathrm{H}$. Heller in Ciba Foundation Colloquia on Endocrinology, G. E. R. Wolstenholme and E. C. P. Millar, Eds. Boston, Little, Brown, 1957, vol. 11, pp. 3-18.

4. Thorn, N. A., and L. Silver. Chemical form of circulating antidiuretic hormone in rats. J. exp. Med. 1957, 105, 575.

5. Heller, J., and J. Stulc. A modified method of titra- 
tion of antidiuretic hormone. Čs. Fysiol. 1958, 7, 466.

6. Cutler, R. E., C. R. Kleeman, M. H. Maxwell, and J. T. Dowling. Physiologic studies in nephrogenic diabetes insipidus. J. clin. Endocr. 1962, 22, 827.

7. Lavietes, P. H. Anaerobic ultrafiltration. J. biol. Chem. 1937, 120, 267.

8. Craig, L. C., and T. P. King. Dialysis in Methods of Biochemical Research, D. Glick, Ed. New York, Interscience, 1962, vol. 10, pp. 178-80.

9. Lauson, H. D., and M. Bocanegra. Clearance of exogenous vasopressin from plasma of dogs. Amer. J. Physiol. 1961, 200, 493.

10. Ginsburg, M. J. The clearances of vasopressin from the splanchnic vascular area and the kidneys. J. Endocr. 1957, 16, 217.

11. Ginsburg, M., and H. Heller. Clearance of injected vasopressin from the circulation and its fate in the body. J. clin. Endocr. 1953, 9, 283.

12. Sawyer, W. H., W. Y. Chan, and H. B. Van Dyke. Antidiuretic responses to neurohypophyseal hormones and some of their synthetic analogues in dogs and rats. Endocrinology 1962, 71, 536.

13. Knox, W. E., V. H. Auerbach, and E. C. C. Lin. Enzymatic and metabolic adaptations in animals. Physiol. Rev. 1956, 36, 164.

14. Spector, William S. Handbook of Biological Data. Philadelphia, W. B. Saunders, 1956, p. 340.

15. Bocanegra, M., and H. D. Lauson. Ultrafiltrability of endogenous antidiuretic hormone from plasma of dogs. Amer. J. Physiol. 1961, 200, 486.

16. Ginsburg, M., and M. W. Smith. The fate of oxytocin in male and female rats. Rrit. J. Pharmacol. 1959, 14, 327 . 